\title{
Strategic Management: A Survival Need for Mexican SMEs
}

\author{
Francisco J. Reyes Avila \\ EGAII, FCQ, Universidad Autónoma de Nuevo León \\ Av. Universidad s/n, Ciudad Universitaria, San Nicolás de los Garza, Monterrey, Nuevo \\ León, México 66451
}

Tel: 52-81-83468455Ｅ-mail: fjra@prodigy.net.mx

Amy Preiss

School of Advanced Studies, University of Phoenix

1625 Fountainhead Parkway, Tempe, Arizona 85282

Tel: 214-319-9552Ｅ-mail: amy.preiss@phoenix.edu

Received: March 25, 2015

doi:10.5296/bms.v6i1.7481
Accepted: April 21, 2015

Published: June 12, 2015

URL: http://dx.doi.org/10.5296/bms.v6i1.7481

\begin{abstract}
Strategic Management is an essential process for small to medium enterprises (SMEs) to manage and survive in a changing business environment. However, Mexican SME managers are not capitalizing on the strategic management process to adapt their businesses to retain competitive advantage. SME managers must employ strategies to maintain competitive advantage while realizing the mission and vision of their organizations. SME managers should develop a professional administration to adapt their businesses to the new environment and consider seeking a consultant for strategic guidance.
\end{abstract}

Keywords: Strategic Management, Mission, Vision, Family Businesses in Mexico 


\section{Strategic Management: A Survival Need for Mexican SMEs}

In order for businesses to sustain competitive advantage in the $21^{\text {st }}$ century business climate, business leaders must adapt their objectives to align with changes in technology, communication, and computer development. According to Chrisholm (1989) the emergence of the information age is the most significant challenge organizations have encountered. Since the 1990s, information has expanded at an unparalleled rate with remarkable advances in the technology for storing, organizing, and accessing data. Jarrar (2004) noted the globalization of technology, liberalization of markets, decreasing lifecycles, and demands for innovation have prompted new leadership and organizational paradigms. While a significant number of American enterprises have successfully adapted to align with these paradigms, Mexican owners of Small Midsize Enterprises (SMEs), must also adapt. These leaders must develop a strategic plan to successfully compete in the $21^{\text {st }}$ century business environment.

Mexican leaders of small and midsized enterprises (SMEs) are important to the Mexican economy because SMEs represent 50\% of the Gross Domestic Product (GDP) for México and $70 \%$ of the employment opportunities for Mexican workers (Plan de Desarrollo Nacional, 2007). The majority of small and midsized enterprises in Mexico are family-owned businesses (Erdener, 2009). According to Erdener, (2009), México ranks fifth in the world in the number of family-owned businesses, but approximately $75 \%$ of these businesses are bankrupt within two years of startup. (Lopez, Salazar, Contreras, \& Soto, 2009). To support entrepreneurship in Mexico, only two months after taking office in 2013, President Enrique Peña Nieto signed a ruling that established the Institute of National Entrepreneurship (Instituto Nacional del Emprendedor). The goal of the Institute was to promote entrepreneurship by encouraging creativity and increasing business productivity. As Mexico's small and midsized businesses began to emerge, their founders lacked the ability to further their growth or sustain them. Saldarriaga and Rios (2007) noted the following may have contributed to Mexican SME owners' inability to sustain their businesses:

- $\quad$ Lack working capital

- Ineffective leadership

- $\quad$ Lack of market knowledge

- A low level of quality in the production of goods or services

- Inability to adapt to the changing business environment

Despite the development of the Institute of National Entrepreneurship and opportunities created by the North American Free Trade Agreement (NAFTA), SME leaders have experienced difficulty maintaining competitive advantage (Moreno-Brid, Santamaria, Rivas, \& Valdivia, 2005). Moreno-Brid et al. (2005) stated, "the launch of NAFTA opened an unprecedented window of opportunity to export to the US, the largest world market" (p. 1104). The Mexican government officials signed NAFTA to increase and diversify exportations, attract foreign direct investment, and to create economic growth of the Mexican 
economy (Villarreal \& Cid, 2008). Owners of small and midsize enterprises (SMEs) have been unable to take advantage on NAFTA due to lack of strategic planning, lack of professional management, lack of financial resources, obsolete business techniques and lack of relevant literature (Saldarriaga \& Rios, 2007).

\section{Lack of Literature}

To obtain information on strategically managing their businesses, Mexican owners of SMEs need validated literature on strategic management for the small and mid-sized sector. This literature appears to be unavailable. De La Rosa (2000) noted the literature on Mexican Small Midsize Enterprises (SMEs) is primarily published via public institutions, governmental institutions, and business chambers of commerce. The literature is not scientifically validated or peer reviewed and does not address SMEs challenges in the global environment. Reyes (2012) found that although the literature on Mexican business is extensive, it lacks peerreview, is often inaccurate, and does not address business needs by sector (micro, small, and midsize. According to De la Rosa (2000) the literature on Mexican SMEs is focused on political and academic perspectives which do not address the specific needs of contemporary Mexican small and midsized business owners.

\section{Strategic Management for the Mexican SME}

To sustain and grow, Mexican leaders of small and midsized enterprises (SMEs) must adjust to align with the $21^{\text {st }}$ century business climate, but are struggling to adapt. According to Saldarriaga Rios (2007), Mexican SME leaders can reach their business goals by creating a strategic plan. Strategic planning is a management activity used to establish business priorities, allocate resources, bolster operations, ensure employees are achieving common goals, establish agreement about desired outcomes, and evaluate and adjust the company's direction in response to environmental and market shifts. David (2008) noted that strategic planning is a methodical effort focused on the future of the organization. Successful strategic planning results in decisions and actions that determine the organization's future direction, the behaviors and actions needed to achieve success, and a process for evaluating outcomes. The strategic planning process starts with a statement of a company's vision and mission followed by a SWOT analysis of the company's strengths, weaknesses, opportunities and threats. After creating the vision and mission and conducting a SWOT analysis, management creates, executes, and monitors a business strategy. Diaz (2010) found a positive correlation between strategic management and Mexican SME business success. Despite its importance, only 35.8 of Mexican SME leaders have strategic planning skills (Medina Elizondo, Ballina Rios, Barquero Cabrero, Molina Morejon, \& Guerrero Ramos, 2011). The challenge for Mexican SME leaders is to create a cohesive vision, mission, and strategic business plan.

\subsection{Creating a Vision}

In creating a business value, Drucker as cited in Hesselbein and Goldsmith (2006) suggested leaders consider the following questions: 
- What is the mission of the business?

- Who are the customers, and non-customers?

- Who are the competitors?

- What are the most important business outcomes?

- How does the business capitalize on opportunities and innovation?

Since family-owned businesses represent a large percentage of Mexican SMEs, leaders must engage the family in creating the vision for the company (Avendano-Alcara, Kelly, Trevinyo-Rodriguez,, \& Madero Gomes, 2009). The vision statement resolves the question about what the company wants to become. In determining the vision, small family owned enterprises should develop a professional administration and decide how they will maintain competitive advantage to create value for customers. In 2013-2014, the Mexican government invoked significant changes in the country's economic structure to create a global growth mindset. These reforms presented a challenge to SME leaders to adapt their enterprises to achieve their visions and goals. In the new Mexican economy, SME leaders must be creative and innovative. Innovation is essential for leaders to create different products or services to capitalize on the company’s competitive position (Rigsby \&Greco, 2003).

To be visionary and creative, Mexican leaders must be proactive in the political, economic, technological, and legal environments of the New Mexican Economy. The first step is for leaders to analyze the economic sector of their particular enterprises such as: tourism, manufacturing, food, etc. The effects of the various reforms differ in each industrial sector. For example, due to a new reform impacting the food industry, junk food in Mexico will incur a special tax. Businesses will pay an $8 \%$ tax on products with 275 calories per 100 grams of sugar or more. The visionary-creative leader will have to determine how to change the mix of ingredients to avoid paying this tax. Additionally, visionary leaders must think about the impact of corruption in the Mexican environment and its effect on the implementation of reforms. Corrupted groups are a threat to the success of private enterprise and potentially helpful government programs because personal interest in profit making is in conflict with governmental programs, reforms, and public interest (Mazcorro-Tellez \& Rodriguez-Prego, 2005).

SME leaders must also understand their competitors and suppliers in and outside of the industrial sector. For example, in Mexico, gas stations have one supplier (Petrolos Mexicanos) PEMEX (owned by the Mexican government), but certain reforms will allow the participation of more suppliers which increases competition. Leaders must assess the level of risk, as new competitors enter the market by proactively planning for the future. In Mexico, 
SME leaders and business students are enrolling in special entrepreneurship courses. One of the main objectives of the Institute of National Entrepreneurship is to promote an Entrepreneurial Spirit around the world working with The Cisco Entrepreneur Institute (Instituto del Emprendedor, 2015). SMEs leaders should enroll in these entrepreneurship courses to enhance their entrepreneurial skills and their capacity to envision future business opportunities, manage risk, develop creativity, and adopt an attitude of perseverance. This knowledge will not only help Mexican SME leaders develop entrepreneurial spirit but enhance professional management which has been a long standing deficit of the Mexican business owner. Mexican SME small business leaders can also consider hiring a business consultant to assist them to professionally manage the business and further capitalize on the vision.

\subsection{Creating a Mission}

According to David (2008), the mission is a statement of the overall purpose of the business. The mission statement reveals what market niche organizational leaders want to fill. The mission usually includes statements about customers, products or services, markets, technology, survival, growth, profitability, philosophy, self-concept, concern for public image, and concern for employees. Hesselbein and Goldsmith (2006) noted that a company's mission statement defines the nature, purpose, and future of the company and is critical to success. Payne (2008) stated developing a mission statement requires finding answers to three questions: Where are we now? Where do we want to be? and Jow are we going to get there? SME leaders must answer these questions to prevail and adapt their business in the changing environment.

Many of the SMEs in México have been family businesses since their establishment and have special roles developing the economy of the country. Chirico (2008) defined a family business as a "business that will be passed on from generation to generation" (p. 434). The main advantages of family businesses are the family's business knowledge, experience, and creativity of the founder of the enterprise. The main disadvantages are a lack of resources, limited market knowledge, and inexperienced management (Rodriguez Pardo \& Martinez, 2006). Despite the disadvantages of owning a family business, founding leaders typically have deep knowledge of their companies. These leaders are visionaries and successful businessmen with a mission to transmit their knowledge to their next generations. An experienced business Consultant often can provide advice on how to achieve successful transfer to either family members or a third-party member, resolve familial conflict, and maintain the continuity of the business through targeted succession planning.

Chirico (2008) noted the family organization may require help to concretize the mission and avoid potential inter-generational family conflict. A business consultant can help each family member capitalize on individual business strengths and view each member's knowledge as a key ingredient for the enterprise to succeed. The consultant can help the family appreciate that each member's business knowledge is part of a succession plan to pass on accumulated knowledge over time. Knowledge accumulation is a source of a competitive advantage that 
enables enterprise leaders to be innovative and competitive.

\section{Conducting a SWOT Analysis}

According to David (2008), a SWOT analysis is an evaluation of an organization's strengths, weakness, opportunities, and threats. During a SWOT analysis, the organization's management team identifies the internal and external factors potentially affecting the business's future performance. Strengths and weaknesses are the organization's internal factors. Opportunities and threats are environmental factors external to the organization. Organizations conduct SWOT analyses as part of the overall corporate planning process to establish financial and operational goals for the upcoming year and strategies for achieving these goals. Conducting a SWOT analysis is an important process for Mexican family-owned businesses to assess the organization's viability and ability to compete. An external consultant can help the family identify the organization's strengths, weaknesses, opportunities and threats.

1. Strengths - opportunities (SO). In assessing the company's strengths and opportunities, the consultant should advise the family to select at most 10 strengths and 10 opportunities, which affect the enterprise from a micro-macro environmental perspective. For example, the enterprise has a special loan and support from the Mexican government to export its products to Central America, and the enterprise is working at $50 \%$ of its capacity. The consultant can help the enterprise create an export strategy and use business strengths to capitalize on opportunities.

2. Weakness - opportunities (WO). In assessing the company's weaknesses and opportunities, the consultant should advise the family to select at most 10 strengths weaknesses and 10 opportunities, which affect the enterprise from a micro-macro environmental perspective. For example, the construction of a highway is affecting the enterprise's sales, but the enterprise has money to buy land in a better location. The consultant can help the business take advantage of the opportunity to buy land for new construction to increase sales.

3. Strengths - threats (ST). In this section, the consultant should advise the family to select at most 10 strengths and 10 threats, which affect the enterprise from a micro-macro environmental perspective. For example, one business objective is to increase revenues by $25 \%$, but a new competitor could threaten the objective. One solution, since the company has strong cash flow, is to hire additional sales consultants.

4. Weakness - threats (WT). In this section, the consultant should advise the family to select at most 10 weaknesses and 10 threats which affect the enterprise from a micro-macro environmental perspective. For example, the accounts payable process is understaffed to manage the number of incoming receivables. The consultant might offer advice to hire an accounts payable clerk either inside or outside the family and aid in the hiring process. 
5. On completion of the SWOT analysis, the consultant and family team should analyze outcomes to best capitalize on strengths and opportunities and minimize weaknesses and threats.

\section{Formulating the Strategy}

The Consultant, family team, and key employees should formulate a business strategy aligned with the vision, mission and outcome of the SWOT analysis. They should go to the Mexican government to apply for assistance to advance their specific strategy or strategies. Some Mexican government institutions include: Institute of National Entrepreneurship, BANCOMEXT, NAFINSA, Pro-Mexico, etc.

\subsection{Implementing the Strategy}

According to David (2008), implementing the business strategy requires strong leadership motivation. The formulation of the strategy is an intellectual process using intuitive-analytical abilities. The main difference between strategy formulation and strategy implementation is that strategy formulation is an intellectual process involving one small group, while strategy implementation is an action orientated process involving all employees. David (2008) noted that implementation is the most complicated part of strategic management process. The implementation process consists of applying the strategy in all functional areas of the enterprise. The family team must consider the multiple roles employees often hold. One of the biggest challenges in the implementation process is sufficiently communicating the strategy to all employees. Kaplan and Norton (2004) noted that only $10 \%$ of business leaders successfully implement their strategy. The remaining $90 \%$ fail to effectively communicate the strategy. A business consultant can provide strategic guidance on implementing annual objectives, designing new policies, allocating resources, minimizing resistance to change, developing a culture aligned with the strategy, and designing compensation and benefit structures.

\subsection{Evaluating the Strategy}

According to David (2008) evaluating the strategy is vital because leaders can detect and correct problems early on. Using a balanced scorecard, leaders can make the necessary adjustments to employees' performance in achieving strategic objectives. Leaders can measure performance in four areas: financial, customer satisfaction, internal process knowledge, and enterprise growth (Kaplan \& Norton, 2004). According to Kaplan and Norton (2004), leaders can measure the effectiveness of their strategy by assessing their competitors' reactions, evaluating overall organizational performance and profitability, and potential cooperation with competitors. Evaluating the strategy in a family business could be challenging to a consultant. In many Mexican family owned businesses, the team lacks administrative management skills and requires education. The consultant can educate the family about evaluating the success or failure of the strategy and provide feedback on how to course correct when necessary. One family team member must assume responsibility for ensuring the family implements the consultant's strategic advice. 


\section{Conclusion}

Mexican SME leaders must adapt business strategy to maintain competitive advantage and achieve business goals. The globalization of technology, liberalization of markets, decreasing lifecycles, and demands for innovation have prompted new leadership, organizational, and economic paradigms. Mexican owners of Small Midsize Enterprises (SMEs) have struggled to adapt to these paradigms. Strategic management is a useful tool for Mexican SME leaders to adapt their organizations and develop competitive advantage for their enterprises.

\section{References}

Avendano-Alcara, J., Kelly, L., Trevinyo-Rodriguez, R. N., \& Madero Gomes, S. (2009). A family-based competitive advantage: Handling key success family factors in Mexican family businesses. Cuadernos de Administración, 22(39), 121-212.

Chrisholm, M. (1989). Presidential committee on information literacy: Final report. Association of College and Research Libraries. Retrieved from http://www.ala.org/ala/acrl/acrlpubs/whitepapers/presidential.htm

David, F. R. (2008). Conceptos de administración estratégica. (11 $1^{\text {th }}$ ed.). México, DF: Prentice Hall.

De la Rosa, A. (2000). La micro, pequeña y mediana empresa en México: sus saberes, mitos y problemática. Iztapalapa, 48(1), 183-220.

Diaz, S. J. (2010). Strategic planning and implementation processes impacting small business success in Mexico: A correlational study. Published doctoral dissertation, University of Phoenix. Retrieved from ProQuest database.

Erdener, C. (2009). Family business \& industrial groups in México. Journal International Business, \& Economics, 9(2), 44-54.

Hesselbin, F., \& Goldsmith, H. (2006). The leader of the future. San Francisco, CA: Josseay-Bass.

Instituto Nacional del Emprendedor (2013). Diario Oficial de la Nacion. Retrieved from http://www.dof.gob.mx/

Jarrar, Y. (2004). Performance measurement in the $21^{\text {st }}$ century from performance measurement to performance management. Business Process Management Journal, 10(5), 1-2. http://dx.doi.org/10.1108/bpmj.2004.15710eaa.001

Kaplan, R. S, \& Norton, D. P. (2004). Strategy maps. Boston, MA: Harvard Business School Publishing Corporation.

López Salazar, A., \& Contreras, S. R. (2009). Desarrollo de la pequeña y mediana empresa: Implicaciones de la orientación emprendedora. Revista Internacional Administración \& Finanza, 2(1), 1-18. 


\section{Macrothink}

Business Management and Strategy

ISSN 2157-6068

2015, Vol. 6, No. 1

Medina, E. M., Ballina, R. F., Barquero, C. J. D., Molina, M. V. M., \& Guerrero, R. L. (2011). Analisis estrategico para el desarrollo de la micro, pequeña y mediana empresa en el Estado de Coahuila, Mexico. Revista Internacional Administracion\& Finanzas, 4(3), 1-20.

Moreno-Brid, J. C., Santamaría, J., \& Rivas Valdivia, J. R. (2005). Industrialization and economic growth in México after NAFTA: The road travelled. Development and Change, 36(6), 1095-1119. http://dx.doi.org/10.1111/j.0012-155X.2005.00451.x

Payne, J. (2008). Management accounting-business strategy. Financial Management, 1, 53-55.

Presidencia de la Republica Mexicana (2007). Plan de Desarrollo Nacional. Retrieved from http://pnd.calderon.presidencia.gob.mx/index.php?=pequeñas-y-medianas-empresas

Reyes Avila, F. J. (2012). The effect of governmental policies for international consolidation of small and midsize enterprises in Mexico. Published doctoral dissertation, University of Phoenix). Retrieved from ProQuest database.

Rigsby, J., \& Greco, G. (2003). Mastering strategy: Insights from the world's greatest leaders and thinkers. New York, NY: McGraw Hill.

Rodríguez, P. A., \& Martínez, F. (2006). Las múltiples caras de las empresas familiares. Debates IESA, XI(2), 35-37.

Ruiz, M. R. (2012). Las PYMES: El Cuarto Sector de la Economia. Global Conferenceon Business and Finance Proceedings, 7(2), 828-832.

Saldarriaga, R. J. G. (2007). Factores determinantes de la competitividad de las empresas Antiqueñas en el contexto de la globalización. El Agora USB, 7(1), 65-76.

Svirina, A. (2010). Measuring managerial efficiency: A balanced approach. Global Journal of Business Research, 4(1), 97-104.

Villarreal, M. A., \& Cid, M. (2008). NAFTA and the Mexican economy. Congressional Research Service. Retrieved from http://search.ebscohost.com.ezproxy.apollolibrary.com/

\section{Copyright Disclaimer}

Copyright reserved by the author(s).

This article is an open-access article distributed under the terms and conditions of the Creative Commons Attribution license (http://creativecommons.org/licenses/by/3.0/). 